\title{
INTERCONNECTION OF STUDENTS' SOMATIC TYPE WITH SOMATIC HEALTH
}

\author{
Baskevich O.V.
}

Vasyl Stefanyk Precarpathian National University

\begin{abstract}
Purpose: to study interconnection of students' somatic type with their somatic health. Material: in the research 106 students of 17-22 years' age participated. Anthropometric indicators were determined. Results: we calculated indices, which characterize reserve potentials of cardio-respiratory system. Students with micro-somatic body constitution have low values of heart beats rate and high diastolic blood pressure. In macro-somatic students we observed confidently higher heart beats rate indicator. By this indicator the students have also restricted range of organism's compensatory potentials. Macro-somatic students with high values of Robinson's index can be related to group with reduced functional reserves of cardio-vascular system. Conclusions: it is recommended to consider that increase of body length and heart beats rate indicators negatively impact on students' somatic health. It is recommended to distribute students, considering main anthropometric indicators.
\end{abstract}

Key words: anthropometry, somatic type, cardio-respiratory system, students.

\section{Introduction}

One of current issues of modern theory and practice of physical culture (PC) is perfection of methodic base of students' physical education. Discussion among physical culture specialists on strategy and technology of educational programs' realization shall be based on theoretical and scientific foundation and increasing of methodic techniques' share. These techniques shall permit to group students by level of heir physical condition $(\mathrm{PhC})$ and somatic health $(\mathrm{SH})[1,3$, $6,19]$.

Development, implementation and further perfection of educational programs are impossible without knowledge of diagnosis methods and assessment of students' indicators. Recent years much attention has been paid by scientists to express diagnosis and different markers of organism's morphological-functional status; organism's genetically determined characteristics. These indicators reflect basic level of students' readiness for fulfillment of socially significant functions. Among modern approaches to solution of this problem analysis data of correlation between somatic indicators and somatic health take special place. Interest to somatic type indicators is not occasional. This complex of physical characteristics is genetically determined and strictly individual. It is determined by organism's morphological features. Most of such features remain unchangeable during all life [2, 5, 9.11, 14].

Recent decade, a steady trend to weakening of Ukrainian population's somatic health has been observed [7, 21]. The quantity of different diseases, connected with chromosomes' structural anomalies, sharply increased among students. It influences on somatic type (ST) of every person. In literature there is a number of works, in which the data about peculiarities of somatic type and somatic health with rheumatism, infectious-allergic diseases, vegetative-vascular dystonia congenital defects, neuropathy of different genesis are elucidated. Besides, gender and age similarity of these indicators was found $[2,4,9]$. Alongside with it there is no works, devoted to complex analysis of PhC of students of all somatic types in respect to their somatic health and physical workability. All above said determined the importance of our research.

Purpose, tasks of the work, material and methods

The purpose of the work is to study interconnection of students' somatic type with their somatic health. The methods and organization of the research: in the research 106 students of 17-22 years' age, who studied in Vasyl Stefanyk Precarpathian National University and lived in Ivano-Frankovsk, participated. In the process of our work we measured body length $(\mathrm{BL}, \mathrm{cm})$, Body mass $(\mathrm{BM}, \mathrm{kg})$, chest circumference in breathing pause $(\mathrm{CC}$, $\mathrm{cm})$, heart beats rate (HBR, bpm), systolic blood pressure (SBP, mm.merc.col.) and diastolic BP (DBP, mm.merc.col.), vital capacity of lungs (VCL, $\mathrm{ml}$ ) and muscular strength of working hand $(\mathrm{MSH}, \mathrm{kg})$. We calculated the following indices:

Weight-height index (WHI) - correspondence of body mass to body length, which was assessed by centile tables;

Life index $(\mathrm{LI})=\mathrm{VCL} / \mathrm{BV}(\mathrm{ml} / \mathrm{kg})$;

Power index $(\mathrm{PI})=\mathrm{MSH} / \mathrm{BM}(\%)$;

Robinson's index (RobI) $=($ HBR x SBP) : 100 (conv.un.);

Ruffiet's index (RufI) - cardio-vascular system's reaction to dozed physical load (30 squats per minute).

Determination of somatic health level was carried out by method of L. Apanasenko [2]. General assessment of somatic health was fulfilled by converting of quantitative indicator (indices) into points. Their sum corresponded to certain level of aerobic (energy potential. Distribution of students into micro-, meso-, and macro somatic groups was realized by schema [4, 14]. Somatic type was estimated by sum of centile intervals' numbers, received for body mass, length and chest circumference. For micro somatic students the sum of centile tables' corridors did not exceed 11, for meso-somatic 
group it was within from 11 to 15 , in macro-somatic group it was higher than 16 [8, 18, 19]. All indicators were processed with calculation of mean values, error of mean value, Student's t-criterion. Correlation analysis was conducted.

Results of the research

Analysis of somatic types of the tested students showed that the highest specific gravity belongs to meso-somatic students (70. 4\%). Girls of micro- and macro- somatic types are rather rare (17. 5\% and 12.1\% respectively). Mean values of morphological functional indicators of general sample and of girls with different somatic types are given in table 1.

Table 1. Morphological-functional indicators of 17-22 years' old students

\begin{tabular}{lllll}
\hline Indicator & Micro-somatic & Meso-somatic & Macro-somatic & P \\
& type & type & type & \\
& $\mathbf{1}$ & $\mathbf{2}$ & $\mathbf{3}$ & \\
\hline BM, kg & $57,5 \pm 0,7$ & $64,8 \pm 0,3$ & $75,0 \pm 0,6$ & $1-2 ; 1-3 ; 2-3$ \\
BL, cm & $146,5 \pm 1,1$ & $155,3 \pm 0,3$ & $161,8 \pm 0,6$ & $1-2 ; 1-3 ; 2-3$ \\
CC, cm & $67,6 \pm 0,5$ & $74,5 \pm 0,3$ & $82,6 \pm 1,0$ & $1-2 ; 1-3 ; 2-3$ \\
HBR, bpm & $80,2 \pm 1,2$ & $82,7 \pm 0,6$ & $85,4 \pm 1,2$ & $1-2 ; 1-3 ; 2-3$ \\
SBP, mm.merc.col. & $106,5 \pm 1,0$ & $105,3 \pm 0,5$ & $105,9 \pm 1,2$ & - \\
DBP, mm.merc.col. & $69,3 \pm 0,7$ & $67,4 \pm 0,4$ & $68,2 \pm 0,9$ & $1-2$ \\
VCL, ml & $2464,0 \pm 38,1$ & $2831,6 \pm 21,3$ & $3422,1 \pm 65,8$ & $1-3$ \\
MSH, kg & $20,6 \pm 0,5$ & $25,2 \pm 0,2$ & $30,0 \pm 0,6$ & - \\
LI & $61,8 \pm 1,4$ & $52,5 \pm 0,5$ & $44,5 \pm 1,4$ & $1-2 ; 1-3 ; 2-3$ \\
PI & $55,9 \pm 1,5$ & $45,6 \pm 0,6$ & $36,3 \pm 1,0$ & $1-2 ; 1-3 ; 2-3$ \\
RobI & $85,4 \pm 1,5$ & $87,2 \pm 0,7$ & $90,4 \pm 1,7$ & $1-3 ; 2-3$ \\
RufI & $10,5 \pm 0,4$ & $11,1 \pm 0,2$ & $11,9 \pm 0,5$ & $1-3$ \\
WHI & $-1,2 \pm 0,09$ & $-0,8 \pm 0,03$ & $-0,2 \pm 0,05$ & $1-2 ; 1-3 ; 2-3$ \\
\hline
\end{tabular}

One of the most important indicators of students' health is physical condition, for characterizing of which anthropometric indicators are measured and assessed. Results of testing showed that in the tested students' groups' body mass, length and chest circumference mean values were within age standards. Analysis, considering somatic type, witnesses that students of micro somatic type have mainly values below average. Macro-somatic students have values average and high. For students with micro- and meso-somatic type average degree of weight-height correlation is characteristic. Macro-somatic students relate to category "above average" by this indicator.

It was found that micro-somatic students have slow temp of growth, meso-somatic students - normal and macro-somatic students - accelerated temp.

Vital capacity of lungs is an important indicator of physical condition. Assessment of received results showed the trend to increase VCL absolute values with increasing of body constitution's strength. The other picture is observed if to regard this indicator per $1 \mathrm{~kg}$ of body mass.

Calculation of life index showed that micro-somatic students have high values of this indicator (see table 1) and it was above average. Mena group LI value of meso-somatic students corresponded to average value and of macrosomatic students - to low level. So, micro-somatic students can be related to group with slowed physical development by main indicators of physical condition (body mass and length, CC). However, they are functionally better developed than their peers, who have higher anthropometric indicators. Comparison of mean group values by muscular strength of hand of students with different somatic type showed confident differences. That is why value of power index (relation of hand's strength to body mass) is confidently higher than of macro-somatic students and was assessed as high. Meso-somatic students showed average values and PI of micro-somatic students was assessed as low.

The tested micro-somatic students have low values of heart beats rate and high diastolic blood pressure (see table 1). Macro-somatic students have confidently higher HBR. It means that in this case cardiac muscle works ineffectively, in the least saving mode and the range of organism's compensatory potentials is restricted [3]. No confident differences between SBP values of students with different somatic type were found.

Valuable criterion of organism's energy potential is condition of cardio-vascular system's condition. One of the most important indicators of this reserve is Robinson's index, which characterizes the work of systolic heart [7, 12, 17]. 
The received by us data witness that in micro-somatic group Robinson's index (RobI) is confidently lower, comparing with students of second somatic type (which was assessed as average). So, macro-somatic students with high Pobinson's index values can be related to group of persons with reduced functional reserves of cardio-vascular system. The received data coincide with results of students' testing in other regions of Ukraine [4, 5, 7]. As per these data macro-somatic students have reduced physical condition indicators and cardio-vascular system's reserves. Ruffiet's index (RufI) reflects adaptation potentials of cardio-vascular systems in response to dozed physical load. Students of all somatic types had reserve of cardio-vascular system's functions below average. Micro-somatic students show much better results.

Somatic health is an integral indicator and for its assessment a number of indices are used. Mean values of somatic health in all sample can be characterized as low. However, students with different body constitution types confidently differ by level of somatic health (see fig.1). Total assessment of somatic health was carried out by converting of quantitative indicators (indices) into points. Their sum corresponded to certain level of aerobic energy potential.

index

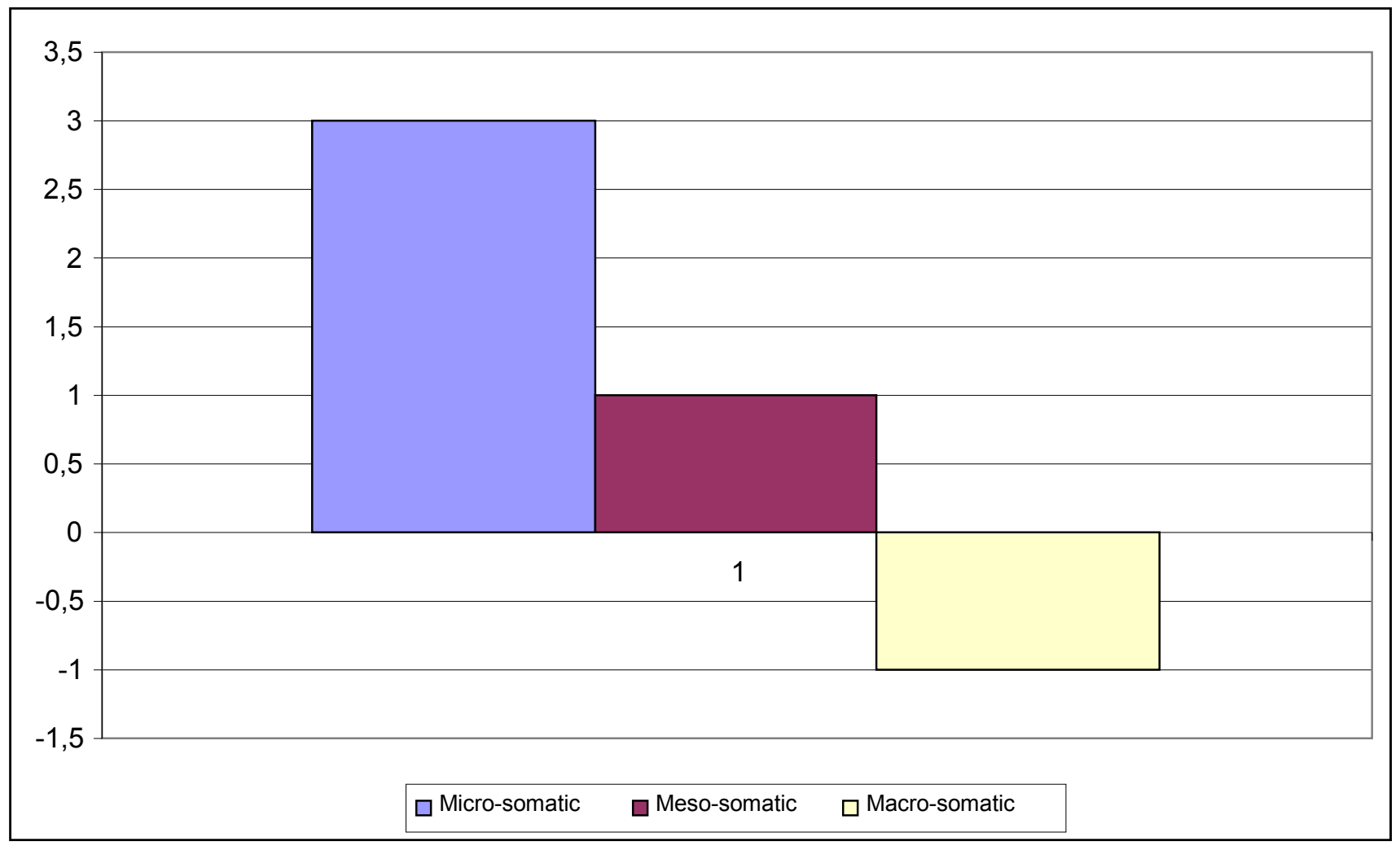

Fig.1. Level of somatic health of different somatic types' students

body constitution

Micro-somatic students have higher mark of somatic health. Their level was assessed as below average. The level of meso- and macro-somatic students was assessed as low.

Individual marks of somatic health are given in table 2.

Among micro-somatic students persons with average, above average and high levels of somatic health are more frequently met. Group with favorable level consisted of micro-somatic students. Among them quantity of persons with low somatic health was less that in other somatic groups. Results of correlation analysis showed that somatic health level is not influenced by SBP and VCL. Increase of body length, mass and heart beats rate indicators negatively impacts on students' somatic health (see fig.2). Weak positive correlation was noticed between somatic health and power, life indices and Robinson's index. Strong positive correlation of these indicators was registered with Ruffiet's index. 
Table 2. The level of girls' somatic health, depending on heir somatic type (quantity of tested, \%)

\begin{tabular}{lccccc}
\hline Characteristic of group & \multicolumn{2}{c}{ Level of somatic health } & & & \\
& High & Above average & Average & Below average & Low \\
\hline All sample & 66,8 & 18,6 & 13,2 & 1,0 & 3,7 \\
Micro-somatic type 1 & 86,9 & 19,1 & 27,0 & 1,1 & - \\
Meso-somatic type 2 & 65,7 & 20,5 & 12,6 & 0,8 & 3,4 \\
Macro-somatic type 3 & 49,4 & 9,8 & 3,3 & 0,0 & 4,0 \\
P<0.05 & $1-2 ; 1-3 ; 2-3$ & $2-3$ & $1-2 ; 1-3 ; 2-3$ & - & - \\
\hline
\end{tabular}

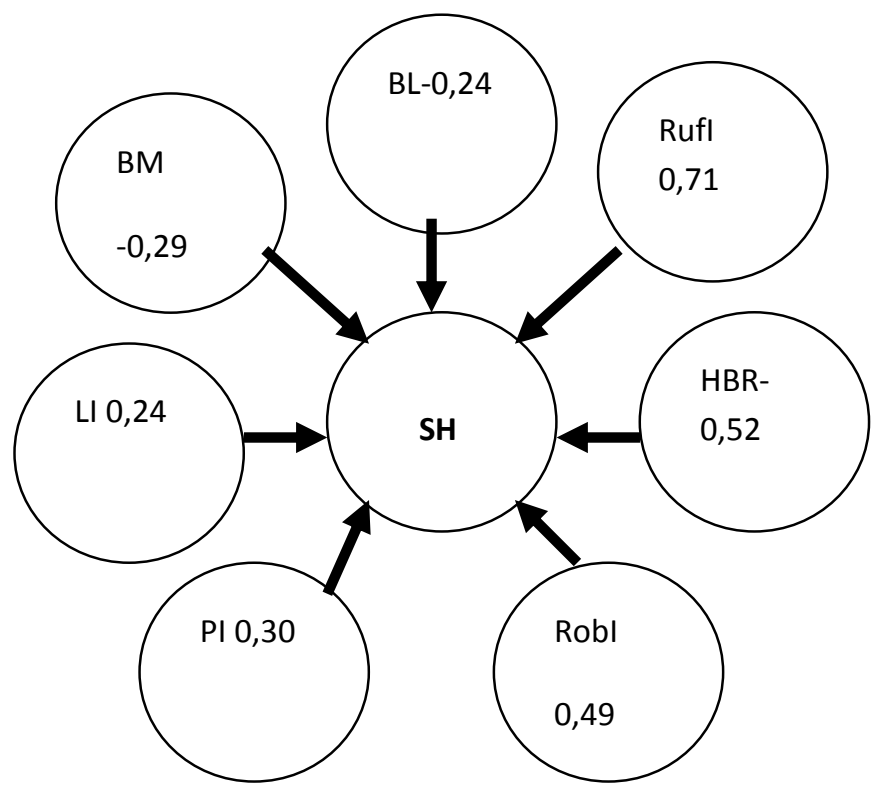

Fig.2 Factors, influencing on students' somatic health (figures are correlation coefficients with $\mathrm{p}<0.05$ ).

\section{Discussion}

Our data confirm results of researches of many authors 1-4], which say that somatic health level is determined by reserve potentials of cardio-vascular system and confidently differs in girls of different somatic types.

The data, permitting to distribute students, considering level of different anthropometric indicators (CC, body mass and body length) into micro-, meso- and macro somatic types seem to be rather promising.

As per traditional approach of health assessment, students' physical condition can correspond to slowed, normal and accelerated temp of development. However, the existing methodic of physical condition's assessment is imperfect. This methodic quantitatively characterizes the process of development but does not permit to judge about systemic genesis state [2]. The results of the conducted researches confirm this statement. Results of correlation analysis were a little sudden. These indicators witness that girls with slowed temp of development (micro-somatic type) have higher reserves of cardio-vascular system and functionally they are in better conditions. That is why they have better somatic health in comparison with meso- and macro-somatic types. It is confirmed in works by Z.Z. Galperin [11] and N.V. Sharipov et al. [17]. The authors note that macro-somatic boys have functional tension and reduced adaptive reserves. That is why such students are of risk group and require increased attention from medical doctors and pedagogues.

\section{Conclusions}

1. Anthropometric indicators are important indicators of students' physical condition. By them somatic health level of all somatic types' students is measured and assessed.

2. Testing results showed that in the tested group of students mean values of body mass, body length and chest circumference were within average age standards. Analysis, considering somatic type, witnesses that micro-somatic students have more values of below average; macro-somatic students - above average and high. Micro- and meso-somatic 
students are characterized by average weight-height correlation. By this criterion macro-somatic students relate to above average category.

3. Calculation of life index showed that micro-somatic students had high value of this indicator (above average). Mean group LI values of meso-somatic students were at average level and meso-somatic students - at low. Micro-somatic students can be related to group with slowed tem of development. However these students functionally are in better condition than their peers with higher anthropometric indicators.

\section{References:}

1. Abramova TF, Zhdanova AG, Nikitina AG. Somatotip - konstitucional'nye markery raznogo urovnia somaticheskogo zdorov'ia [Somatic type - constitutional markers of different somatic health levels]. Nauchnoinformacionnyj sbornik, 2009;2:94-95. (in Russian)

2. Avtandilov GG. Medicinskaia morfometriia [Medical morphological metering]. Moscow: Medicine; 1990. (in Russian)

3. Agadzhanian NA, Marachev AG, Bobkov GA. Ekologicheskaia fiziologiia cheloveka [Ecological physiology of man] Moscow: Kruk; 1999. (in Russian)

4. Apanasenko GL. Ekspres-diagnostika rivnia somatichnogo zdorov'ia [Express diagnosis of somatic health level], Kiev; 2002. (in Ukrainian)

5. Arutiunian AG. Somatotip kak sredstvo prognozirovaniia i otbora $\mathrm{v}$ sporte \{Somatic type as mean of prognostication and selection in sports], Geneticheskie markery v antropogenetike i medicine 2009;1:140 - 141. (in Russian)

6. Baskevich OV, Popel' SL, Duma ZV. Somatometrichna kharakteristika iunakiv Prikarpattia [Somatic metering characteristic of Precarpathian boys]. Visnik Prikarpats'kogo universitetu 2014;20:55-62. (in Ukrainian)

7. Boreckij VM. Somatometricheskie pokazateli konstitucii sportsmenov [Somatic metering indicators of sportsmen's constitution]. Nauchno-informacionnyj sbornik 2010;2:96-97. (in Russian)

8. Vasiruk M, Vasiruk M, Kucherenko V. Fizichnij rozvitok ta somatotip iunakiv 15-17 rokiv Ternopolia sistemi VPTU [Physical condition and somatic type of Ternopol 15-17 years old boys, system of HVTC]. Optimizaciia procesu fizichnogo vikhovannia $v$ sistemi osviti 2003;1:150-152. (in Ukrainian)

9. Vovchenko I. Ocinka rivnia fizichnogo zdorov'ia studentiv [Assessment of students' physical health]. Optimizaciia procesu fizichnogo vikhovannia $v$ sistemi osviti 2003;1:135-137. (in Ukrainian)

10. Glanc S. Mediko-biologicheskaia statistika [Medical biological statistic], Moscow: Practice; 1998. (in Russian)

11. Gal'perina ZZ. Somatotipologiia ukraincev Podol'ia i faktory ee opredeliaiushchie. Cand. Diss. [Somatic typology of Podolye Ukrainians and factors, which determine it. Cand. Diss.], Moscow; 2008. (in Russian)

12. Grebneva NN. Ekologo-fiziologicheskij portret sovremennikh detej i podrostkov v usloviiakh Tiumenskoj oblasti [Ecological-physiological portrait of modern children and adolescents in conditions of Tyumen region], Tyumen: TSU Pub.; 2006. (in Russian). (in Russian)

13. Dorshakova NV. Kachestvo okruzhaiushchej sredi $i$ zdorov'e cheloveka $v$ usloviiakh Karelii [Quality of environment and human health in conditions of Karelia], Petrozavodsk: PSU; 1997. (in Russian). (in Russian)

14. Darskaia SS. Tekhnika opredeleniia tipov konstitucii u detej i podrostkov [Technique of determination of children's and adolescents' constitution], Moscow; 2005. (in Russian)

15. Martirosov EG. Metody issledovaniia v sportivnoj antropologii [Methods of research in sport anthropology], Moscow[ Physical Culture and Sport; 1982. (in Russian)

16. Nikolaev VG, Grebennikova VP. Ontogeneticheskaia dinamika individual'no-tipologicheskikh osobennostej organizma cheloveka [Ontogeny dynamic of individual-typological features of human organism], Krasnoyarsk; 2001. (in Russia).

17. Sharypova NV, Sveshnikov AA. Vliianie somatotipa na adaptivnye reakcii organizma pri ekzamenacionnom stresse [Somatic type's influence on organism's adaptation reactions under examinations' stress]. Sovremennye problemy nauki i obrazovaniia 2007;6:59-64.

18. Shcherbo AP, Masiuk VS. Ekologiia i zdorov'e detej i podrostkov Respubliki Kareliia [Ecology and health of children and adolescents in Karelia Republic]. Petrozavodsk: PSU; 2007. (in Russia).

19. Bożiłow W, Rożnowski J, Fus D, Drozd M, Czaja R, Czarny W. Siatki centylowe dla dzieci i młodzieży regionu Podkarpackiego, Pomorza Środkowego i Radomskiego [Centile schedules for children and young people of Podcarpathian region of Central Pomerania and of Radomskiy region]. Przeglad Naukowy [Scientific review] 2003;1-2:15-20 (in Polish)

20. Cieszkowski S, Drozd M. Dynamika rozwoju motorycznego u dzieci w wieku 7-15 lat z terenów województwa przemyskiego [Dynamic of motor development of 7-15 years old children in districts of Przemysl province]. Przegląd Naukowy [Scientific review] 1997;4(2):5-15. (in Polish)

21. Cieszkowski S, Dubogaj A, Drozd M. Wpływ miejsca zamieszkania na poziom zdolności motorycznych u dzieci w wieku 7-15 lat [Influence of way of life on motor skills' level of 7-15 years old children]. Przegląd Naukowy [Scientific review] 1998;1(2):5-15 (in Polish) 
22. Matiegka J. The testing of physical efficiency. Amer. J. Phys. Antropol. 1921;4:223-230.

\begin{tabular}{|c|}
\hline Information about the author: \\
\hline $\begin{array}{l}\text { Baskevich O.V.; http://orcid.org/0000-0003-0996-6920; } \\
\text { hejlion@gmail.com; Vasyl Stefanyk Precarpathian National } \\
\text { University; } 57 \text { Shevchenko str., 76018, Ivano-Frankivsk, } \\
\text { Ukraine. }\end{array}$ \\
\hline $\begin{array}{l}\text { Cite this article as: Baskevich O.V. Interconnection of } \\
\text { students' somatic type with somatic health. Physical } \\
\text { education } \quad \text { of } \quad \text { students, } \\
\text { http://dx.doi.org/10.15561/20755279.2015.0601 }\end{array}$ \\
\hline $\begin{array}{l}\text { The electronic version of this article is the complete one and can be } \\
\text { found online at: } \mathrm{http}: / / \text { www.sportpedu.org.ua/html/arhive-e.html }\end{array}$ \\
\hline $\begin{array}{l}\text { This is an Open Access article distributed under the terms of the } \\
\text { Creative Commons Attribution License, which permits unrestricted } \\
\text { use, distribution, and reproduction in any medium, provided the } \\
\text { original } \quad \text { work } \quad \text { is } \quad \text { properly } \\
\text { (http://creativecommons.org/licenses/by/4.0/deed.en). }\end{array}$ \\
\hline $\begin{array}{l}\text { Received: } 22.08 .2015 \\
\text { Accepted: } 29.08 .2015 \text {; Published: } 10.09 .2015\end{array}$ \\
\hline
\end{tabular}

